\title{
Effects of Macroeconomic and Global Variables on Stock Market Performance in Mexico and Policy Implications
}

\author{
Yu Hsing ${ }^{1, *}$, Antoinette S. Phillips ${ }^{1}$ \& Carl Phillips ${ }^{1}$ \\ ${ }^{1}$ Department of Management \& Business Administration, Southeastern Louisiana University, \\ SLU Box 10813, Hammond, Louisiana 70402, USA \\ *Corresponding author: Department of Management \& Business Administration, \\ Southeastern Louisiana University, SLU Box 10813, Hammond, Louisiana 70402, USA \\ Tel.: 1-985-549-2086Ｅ-mail: yhsing@selu.edu
}

Received: September 27, 2013 Accepted: November 29, 2013 Published: December 10, 2013 doi:10.5296/rae.v5i4.4717 URL: http://dx.doi.org/10.5296/rae.v5i4.4717

\begin{abstract}
Based on a sample during 1985.Q4-2011.Q2 and applying the exponential GARCH model, we find that the stock market index in Mexico is positively associated with real GDP, the peso/USD exchange rate, the M3/GDP ratio and the U.S. stock market index and negatively affected by the interest rate, the ratio of the government deficit to GDP and the expected inflation rate. Hence, a stronger domestic economy, a lower interest rate, a weaker peso, more money supply as a percent of GDP, fiscal prudence, a stronger U.S. stock market and a lower inflation rate would help stock market performance in Mexico.
\end{abstract}

Keywords: Stock market index, Interest rate, Exchange rate, Money supply, Government deficits, World stock Market index 


\section{Introduction}

Equities or stocks are major financial assets for households to invest and business firms to acquire capital. The rise and fall of stock values would affect households' spending via the liquidity effect and the wealth effect. Changes in stock prices would also affect businesses' financial strengths and investment decisions through the balance sheet channel, the cash flow channel and Tobin's-q theory. The 2008-2009 financial crisis had caused the Mexican stock market index to decline by as much as $43.57 \%$ compared with the decline of $47.95 \%$ in the U.S. during the period of late 2007 and early 2009.

Although the stock market index in Mexico has risen above the pre-crisis level in recent months, it is interesting to examine the potential impacts of macroeconomic and global variables on stock market performance in Mexico. The selection of Mexico is partly because it has had a close economic relationship with the U.S. since the passage of the NAFTA in 1994 and partly because it is the second largest country in Latin America. The paper will consider several selected variables such as real GDP, the interest rate, the exchange rate, the money supply, government deficits, world stock market performance and the inflation rate. It will study the separate effect of a change in one of these variables on the Mexican stock market index, holding other variables constant. The exponential GARCH (E-GARCH) model will be applied in empirical work in order to address the autoregressive conditional heteroskedasticity of the error term.

There have been several recent studies examining the stock markets in Mexico and related countries. Hasan, Kadapakkam and Ma (2003) investigated whether the random walk hypothesis may hold for eight selected Latin American countries including Mexico. They revealed that the random walk hypothesis applies to Argentina, does not apply to Peru, and may or may not apply to Mexico and the remaining 5 countries.

Fernández-Serrano and Sosvilla-Rivero1 (2003) found strong support for a long-term cointegrating relationship between the S\&P 500 index and the Mexican, Argentine and Chilean stock indexes from April 1999, August 1998 and October 1999, respectively and a long-term cointegrating relationship between the DJIA index and the Argentine, Venezuelan and Chilean stock indexes after the 1998 financial crisis.

Spyrou (2004) examined the relationship between stock return and inflation for 10 selected emerging markets. For Mexico, he found that the relationship was insignificant during 1989M1-1995M12, 1989M1-2000M8, and 1995M12-2000M6.

Abugri (2008) analyzed the impact of macroeconomic variables on stock prices for four Latin American countries based on the VAR model. For Mexico, the stock return is positively affected by the MSCI world stock index, negatively influenced by the U.S. Treasury bill rate and the exchange rate, and not affected by industrial production, the domestic interest rate and the money supply. Bazán and Montes (2012) analyzed the impacts of macroeconomic news on the Mexican stock market return during 2003-2008. They revealed that stock returns in Mexico are associated with the surprise or new information on macroeconomic fundamentals in the U.S. and Mexico. Pierdzioch and Kizys (2012) compared the linkages 
among the stock markets in three NAFTA countries, namely, the U.S., Canada and Mexico based on the fundamentals and speculative bubbles. They showed that the fundamentals have stronger impacts on stock prices than the speculative bubbles. Bazán and Montes (2012) analyzed the impacts of macroeconomic news on the Mexican stock market return during 2003-2008. They revealed that stock returns in Mexico are associated with the surprise or new information on macroeconomic fundamentals in the U.S. and Mexico.

Rivas, Verma, Rodriguez, and Verma (2008) examined the effect of the movements in stock prices in six industrialized countries on the stock markets in Mexico, Brazil and Chile. They found that positive shocks cause less volatility than negative shocks and that stock prices in Mexico and Brazil are more responsive to changes in stock prices in the industrialized countries because of more openness in capital mobility and trade. Jawadi, Arouri and Nguyen (2010) showed that the U.S. stock market affects the stock markets in Mexico and Argentina in the short run whereas there are no long-term linkages. Thus, they maintained that the Mexican and Argentine stock markets are determined by fundamentals in the long run.

Kutty (2010) studied the relationship between exchange rates and stock prices for Mexico. Based on the Granger causality test, stock prices cause exchange rates in the short run while these two variables have no long-term relationship. Walid, Chaker, Masood and Fry (2011) investigated the relationship between exchange rates and stock price volatility for four emerging countries including Mexico. They showed that the relationship is regime dependent and that stock price volatility reacts asymmetrically to changes in the exchange rate.

Some of the above findings need to be reexamined. The lack of a long-term relationship between stock prices and exchange rates and the insignificant coefficients of inflation, industrial production, the domestic interest rate and the money supply for Mexico need to be re-estimated by using a different econometric method to determine whether the findings reported by Spyrou (2004), Abugri (2008) and Kutty (2010) are consistent with the results in this paper.

\section{The Model}

Extending Spyrou (2004), Abugri (2008), Walid, Chaker, Masood and Fry (2011), Pierdzioch and Kizys (2012), Bazan and Montes (2012) and other previous studies, we can express the stock market index in Mexico as:

$$
\begin{aligned}
& \mathrm{SI}=\mathrm{f}(\mathrm{RO}, \mathrm{RT}, \mathrm{ER}, \mathrm{MY}, \mathrm{GD}, \mathrm{WS}, \mathrm{EI}) \\
& \qquad S I_{R O}>0, S I_{R T}<0, S I_{E R}>\text { or }<0, S I_{M Y}>\text { or }<0, S I_{G D}>\text { or }<0, S I_{W S}>, S I_{E I}<0 .
\end{aligned}
$$

where

$$
\begin{aligned}
& \text { SI = the stock market index in Mexico, } \\
& \text { RO = real output, }
\end{aligned}
$$


$\mathrm{RT}=$ the interest rate,

$\mathrm{ER}=$ the exchange rate,

MY = the money supply,

$\mathrm{GD}$ = government deficits,

WS $=$ world stock market index, and

$\mathrm{EI}=$ the expected inflation rate.

Note that $S I_{X}$ is the partial derivative of SI with respect to $\mathrm{X}$, which is one of the explanatory variables on the right-hand side. We expect that the Mexican stock market index is positively affected by real GDP and the world stock market index, negatively influenced by the interest rate and the expected inflation rate, and may be positively or negatively impacted by the exchange rate, the money supply and the government deficit.

Increased real GDP in Mexico means more business opportunities, which are expected to raise stock prices in Mexico (Chen, Roll and Ross, 1986; Fama, 1990; Abdullah and Hayworth, 1993; Mukherjee and Naka, 1995). Stock markets are expected to show the spillover effect, especially from stock markets in advanced countries to stock markets in developing countries (Fernández-Serrano and Sosvilla-Rivero1, 2003; Araújo, 2009; Jawadi, Arouri and Nguyen, 2010). Hence, a higher world stock market index is likely to lead to a higher stock market index in Mexico.

According to the present value model, a higher interest rate causes the present value of future dividends and stock prices to decline. Conversely, a lower interest rate results in an increase in the present value of future dividends and stock prices (Fama, 1981, 1990; Mukherjee and Naka, 1995; Ratanapakorn and Sharma, 2007; Humpe and Macmillan, 2009). A higher expected inflation rate shifts the aggregate supply curve leftward, resulting in a higher price and a lower real output, which, in turn, would reduce sales, profits and stock prices (Fama, 1981; Geske and Roll, 1983; Mukherjee and Naka, 1995).

A depreciation of the peso versus the U.S. dollar would raise import costs and domestic prices, increase export opportunities, cause outflows of foreign capital, and reduce the demand for Mexican stocks and stock price (Nieh and Lee, 2001; Kim, 2003; Ratanapakorn and Sharma, 2007; Abugri, 2008). Thus, the net impact is unclear.

Moderate increase in the money supply would raise the credit available for businesses and consumers and facilitate economic activities and stock market performance. However, too much money is likely to cause high inflation, hurt the economy, and reduce stock prices (Ratanapakorn and Sharma, 2007; Abugri, 2008; Humpe and Macmillan, 2009). Hence, the net effect is uncertain.

Moderate amount of government deficits may be justified to stimulate a sluggish economy, make up the deficiency in aggregate demand in the private sector, and enhance infrastructures for future growth. Nevertheless, huge government deficits beyond certain threshold would 
raise the long-term interest rate, crowd out private spending, and reduce business sales and stock prices (Darrat, 1990a, 1990b). Therefore, the net impact is ambiguous.

\section{Empirical Results}

The data were collected from the 2012 issues of the International Financial Statistics published by the International Monetary Fund. SI is represented by the share price index with 2005 as the base year. RO is represented by real gross domestic product at the 2005 price and measured in billion pesos. The money market rate is chosen for the interest rate. The Treasury bill rate was considered but not chosen due to lack of complete data during the sample period. The exchange rate is expressed as units of the peso per one U.S. dollar. Hence, an increase in the exchange rate means depreciation of the peso, and vice versa. The ratio of M3 money to nominal GDP as a percent is used to represent the money supply (MY). GD is presented by the ratio of the government deficit to nominal GDP as a percent. The U.S. stock market index with 2005 as the base year is used to represent the world stock market index due to its worldwide dominant role. The expected inflation rate is measured by the average inflation rate of the past four quarters. Except for the ratio of the government deficit to GDP and the expected inflation rate with negative values, other variables are measured in the log scale. The quarterly sample runs from 1985.Q4 to 2011.Q2. The data for M3 money supply before 1985.Q4 are not available.

The augmented Dickey-Fuller test on the regression residuals is employed to determine whether these time series variables have a stable relationship. A lag length of one is chosen based on the Schwarz information criterion. The test statistic of -4.417 is greater than the critical value of -2.588 in absolute values at the $1 \%$ level. Hence, these variables are cointegrated and have a long-term equilibrium relationship.

The E-GARCH model is applied in empirical work mainly because it allows the parameters in the variance equation to have negative values. Table 1 reports estimated coefficients, z-statistics, significance levels, and other related statistics. As shown, these seven independent variables can explain approximately $90.5 \%$ of the variation in the stock market index in Mexico. According to the F test, the whole regression is significant at the $1 \%$ level. All the estimated coefficients are significant at the $1 \%$ level. Specifically, the stock market index in Mexico has a positive relationship with real GDP, the peso/USD exchange rate, the M3/GDP ratio and the U.S. stock market index and a negative relationship with the money market rate, the ratio of government deficits to GDP and the expected inflation rate. 
Table 1: Estimated regression of the stock market index in Mexico

\begin{tabular}{lcc}
\hline & Coefficient & z-statistic \\
\hline Real GDP & $3.418^{*}$ & 14.873 \\
Interest rate & $-0.158^{*}$ & -5.848 \\
Exchange rate & $0.138^{*}$ & 2.517 \\
M3/GDP ratio & $1.975^{*}$ & 26.826 \\
Deficit/GDP ratio & $-0.092^{*}$ & $-7 . .705$ \\
U.S. stock market index & $0.286^{*}$ & 4.283 \\
Expected inflation rate & $-0.017^{*}$ & -8.194 \\
Constant & $-19.943^{*}$ & -26.766 \\
Adjusted R-squared & 0.905 & \\
AIC & -0.117 & \\
Schwarz criterion & 0.164 & \\
Sample period & $1985 . Q 4-2011 . \mathrm{Q} 2$ & \\
Number of observations & 103 & \\
\hline
\end{tabular}

* indicates that the estimated coefficient is significant at the $1 \%$ level.

\section{Discussion}

Real GDP and the ratio of M3 to GDP have larger elasticities than other variables in absolute values. For example, if real GDP and the ratio of M3 to GDP rise by 1\%, the Mexican stock market index will increase $3.418 \%$ and $1.975 \%$, respectively. The positive significant sign of the peso/USD exchange rate suggests that positive impacts of peso depreciation on the stock market index such as increased export opportunities overwhelm its negative impacts. The trend shows that the peso has depreciated against the U.S. dollar from 0.372 pesos per U.S. dollar in 1985.Q4 to 13.422 pesos per U.S. dollar in 2011.Q3. Hence, the long-term trend of the exchange rate is in favor of the stock market. The positive significant coefficient of the M3/GDP ratio indicates that a further increase in the money supply relative to GDP would not cause too much concern about its potential negative effect on the stock market index. The negative significant coefficient of the government deficit/GDP ratio implies that more government deficit spending as a percent of GDP would harm stock prices due to its negative impacts on the long-term interest rate and the crowding-out effect. The positive significant impact of the U.S. stock market on the Mexican stock market shows that a weak U.S. stock market is expected to harm the Mexican stock market, and vice versa.

\section{Summary and Conclusions}

This paper has examined the impacts of selected macroeconomic and global variables on the stock market index in Mexico. These variables include real GDP, the money market rate, the peso/USD exchange rate, the ratio of M3 money to GDP, the ratio of the government deficit to GDP, the U.S. stock market index, and the expected inflation rate. The sample ranges from 1985.Q4 to 2011.Q2 with a total of 103 observations. 
A higher real GDP, a lower money market rate, depreciation of the peso, a higher M3/GDP ratio, a lower deficit/GDP ratio, a higher U.S. stock market index, and a lower expected inflation rate would be beneficial to the Mexican stock market. Therefore, Mexican authorities may need to apply these results in conducting monetary, fiscal and exchange rate policies. A combined policy of a stronger economy, a lower interest rate, a lower expected inflation rate, a higher M3/GDP ratio, more fiscal discipline and peso depreciation would help the stock market. Although peso depreciation would help the stock market, it may lead to international capital outflows and an increase in import costs, domestic prices, and inflation. Hence, caution may need to be exercised in considering the depreciation of the peso.

\section{References}

Abdullah, D. A., \& Hayworth, S. C. (1993). Macroeconometrics of stock price fluctuations. Quarterly Journal of Business and Economics, 32, 50-67.

Abugri, B. A. (2008). Empirical relationship between macroeconomic volatility and stock returns: Evidence from Latin American markets. International Review of Financial Analysis, 17, 396-410. http://dx.doi.org/10.1016/j.irfa.2006.09.002

Araújo, E. (2009). Macroeconomic shocks and the co-movement of stock returns in Latin America. Emerging Markets Review, 10, 331-344. http://dx.doi.org/10.1016/j.ememar.2009.08.003

Bazán, R. C., \& Montes, M. P. S. (2012). Impact of macroeconomic surprises from Mexico and the United States on the Mexican stock Market. Economía Mexicana NUEVA ÉPOCA, 21, 35-67.

Chen, N.-F., Roll, R., \& Ross, S. A. (1986). Economic forces and the stock market. Journal of Business, 59, 383-403. http://dx.doi.org/10.1086/296344

Darrat, A. F. (1990a). Stock returns, money and fiscal deficits. Journal of Financial and Quantitative Analysis, 25, 387-398. http://dx.doi.org/10.2307/2330703

Darrat, A. F. (1990b). The impact of federal debt upon stock prices in the United States. Journal of Post Keynesian Economics, 12, 375-389.

Fama, E. F. (1981). Stock returns, real activity, inflation and money. American Economic Review, 71, 545-565.

Fama, E. F., (1990). Stock returns, expected returns, and real activity. Journal of Finance, 45, 1089-1108. http://dx.doi.org/10.1111/j.1540-6261.1990.tb02428.x

Fernández-Serrano, J. L., \& Sosvilla-Rivero1, S. (2003). Modelling the linkages between US and Latin American stock markets. Applied Economics, 35, 1423-1434. http://dx.doi.org/10.1080/0003684032000100409

Geske, R., \& Roll, R. (1983). The fiscal and monetary linkages between stock returns and 
inflation. Journal of Finance, 38, 1-31. http://dx.doi.org/10.1111/j.1540-6261.1983.tb03623.x

Hasan, T., Kadapakkam, P.-R., \& Ma, Y. (2003). Tests of random walk for Latin American stock markets: Additional evidence. Latin American Business Review, 4, 37-53. http://dx.doi.org/10.1300/J140v04n02_03

Humpe, A., \& Macmillan, P. (2009). Can macroeconomic variables explain long-term stock market movements? A comparison of the US and Japan. Applied Financial Economics, 19, 111-119. http://dx.doi.org/10.1080/09603100701748956

Jawadi, F., Arouri, M. E. H., \& Nguyen, D. K. (2010). Stock market integration in Mexico and Argentina: Are short- and long-term considerations different? Applied Economics Letters, 17, 1503-1507. http://dx.doi.org/10.1080/13504850903035899

Kim, K.-H. (2003). Dollar exchange rate and stock price: Evidence from multivariate cointegration and error correction model. Review of Financial Economics, 12, 301-313. http://dx.doi.org/10.1016/S1058-3300(03)00026-0

Kutty, G. (2010). The relationship between exchange rates and stock prices: The case of Mexico. North American Journal of Finance and Banking Research, 4, 1-12.

Mukherjee, T. K., \& Naka, A. (1995). Dynamic relations between macroeconomic variables and the Japanese stock market: an application of a vector error correction model. The Journal of Financial Research, 18, 223-237.

Nieh, C.-C., \& Lee, C.-F. (2001). Dynamic relationship between stock prices and exchange rates for G-7 countries. Quarterly Review of Economics and Finance, 41, 477-490. http://dx.doi.org/10.1016/S1062-9769(01)00085-0

Pierdzioch, C., \& Kizys, R. (2012). On the Linkages of the Stock Markets of the NAFTA Countries: Fundamentals or Speculative Bubbles? International Economic Journal, March 30, online.

Ratanapakorn, O., \& Sharma, S. C. (2007). Dynamic analysis between the US stock returns and the macroeconomic variables. Applied Financial Economics, 17, 369-337. http://dx.doi.org/10.1080/09603100600638944

Rivas, A., Verma, R., Rodriguez, A., \& Verma, P. (2008). International transmission mechanism of stock market volatilities. Latin American Business Review, 9, 33-68. http://dx.doi.org/10.1080/10978520802189302

Spyrou, S. I. (2004). Are stocks a good hedge against inflation? Evidence from emerging markets. Applied Economics, 36, 41-48. http://dx.doi.org/10.1080/0003684042000177189

Walid, C., Chaker, A., Masood, O., \& and Fry, J. (2011). Stock market volatility and exchange rates in emerging countries: A Markov-state switching approach. Emerging Markets Review, 12, 272-292. http://dx.doi.org/10.1016/j.ememar.2011.04.003 


\section{Copyright Disclaimer}

Copyright reserved by the author(s).

This article is an open-access article distributed under the terms and conditions of the Creative Commons Attribution license (http://creativecommons.org/licenses/by/3.0/). 